\title{
Implementasi Pendekatan Andragogi Spiritual dalam Meningkatkan Motivasi Belajar Mandiri Mahasiswa pada Program Studi Pendidikan Bahasa Indonesia FKIP Universitas Muhammadiyah Banjarmasin
}

\author{
Jamiatul Hamidah \\ (corresponding author) \\ Universitas Muhammadiyah Banjarmasin \\ Email: midah.beswan@gmail.com \\ Akhmad Syakir \\ Universitas Muhammadiyah Banjarmasin \\ Email: ahmadsyakir02@gmail.com
}

\begin{abstract}
APA Citation: Hamidah, J. \& Syakir, A. (2021). Implementasi Pendekatan Andragogi Spiritual dalam Meningkatkan Motivasi Belajar Mandiri Mahasiswa pada Program Studi Pendidikan Bahasa Indonesia FKIP Universitas Muhammadiyah Banjarmasin. Silampari Bisa: Jurnal Penelitian Pendidikan Bahasa Indonesia, Daerah, dan Asing, 4(2), 358-372. https://doi.org/10.31540/silamparibisa.v4i2.1376
\end{abstract}

\begin{abstract}
Abstrak
Metode perkuliahan yang dilakukan oleh dosen sangat berpengaruh terhadap hasil yang nantinya akan dicapai oleh mahasiswa, baik itu mencakup proses belajar-mengajar, penugasan, maupun pada saat ujian. Pendekatan andragogi spiritual memberikan kebebasan kepada mahasiswa untuk menumbuhkan kemandirian belajar, kesadaran terhadap pengembangan potensi diri, dan motivasi untuk meraih tujuan belajar. Penelitian ini bertujuan untuk mendeskripsikan penerapan pendekatan andragogi spiritual dalam perkuliahan untuk mengoptimalkan hasil belajar mahasiswa. Penelitian ini menggunakan metode deskriptif dengan pendekatan kualitatif. Metode yang digunakan dalam pengumpulan data adalah wawancara dan pembagian angket terbuka kepada dosen dan mahasiswa. Sumber data diperoleh dari 40 orang mahasiswa dan 6 orang dosen pada Program Studi Pendidikan Bahasa Indonesia, FKIP, Universitas Muhammadiyah Banjarmasin. Hasil penelitian menunjukkan bahwa penerapan pendekatan andragogi spiritual dapat meningkatkan motivasi dan hasil belajar mahasiswa. Pendekatan andragogi spiritual merupakan sebuah pendekatan pembelajaran bagi orang dewasa yang menekankan pada spirit atau kejiwaan peserta didik pada tingkat dewasa. Pada Program Studi Pendidikan Bahasa Indonesia, penerapan pendekatan ini dilakukan di berbagai aspek dengan berlandaskan penanaman nilai Al-Islam Kemuhammadiyahan. Penerapan tersebut dilakukan oleh dosen mulai dari persiapan pembelajaran, proses kegiatan pembelajaran, sampai kegiatan penilaian atau evaluasi.
\end{abstract}

Kata kunci: implementasi, pendekatan andragogi spiritual, motivasi belajar mandiri, mahasiswa 
Jamiatul Hamidah, Akhmad Syakir

Implementasi Pendekatan Andragogi Spiritual dalam Meningkatkan Motivasi Belajar Mandiri Mahasiswa pada Program Studi Pendidikan Bahasa Indonesia FKIP Universitas Muhammadiyah Banjarmasin

\title{
Implementation of the Spiritual Andragogy Approach in Increasing Students' Independent Learning Motivation at the Indonesian Language Education Study Program FKIP University of Muhammadiyah Banjarmasin
}

\begin{abstract}
Lecture methods carried out by lecturers greatly affect the results that will be achieved by students, whether it includes the teaching and learning process, assignments, and during exams. The spiritual andragogy approach gives freedom to students to grow independent learning, awareness of self-potential development, and motivation to achieve learning goals. This study aims to describe the application of a spiritual andragogy approach in lectures to optimize student learning outcomes. This study uses a descriptive method with a qualitative approach. The method used in data collection is interviews and the distribution of open questionnaires to lecturers and students. Sources of data were obtained from 40 students and 6 lecturers at the Indonesian Language Education Study Program, FKIP, University of Muhammadiyah Banjarmasin. The results showed that the application of a spiritual andragogy approach could improve student motivation and learning outcomes. The spiritual andragogy approach is a learning approach for adults that emphasizes the spirit or psychology of students at the adult level. In the Indonesian Language Education Study Program, the application of this approach is carried out in various aspects based on the inculcation of the values of Al-Islam Kemuhammadiyahan. The application is carried out by lecturers starting from learning preparation, the process of learning activities, to assessment or evaluation activities.
\end{abstract}

Keywords: implementation, spiritual andragogy approach, self-study motivation, students

\section{A. Pendahuluan}

Pada semester pertama perkuliahan, sering kali ditemukan mahasiswa yang masih bingung dengan gaya belajar di perguruan tinggi. Jika sebelumnya di sekolah menengah mereka terbiasa menerima pelajaran dari guru, di perguruan tinggi mereka harus lebih aktif belajar mandiri. Bukan hanya dari segi cara belajar, kegiatan kuliah mempunyai banyak perbedaan dengan sekolah. Di antara perbedaan itu adalah kondisi latar belakang usia mahasiswa yang tidak lagi berstatus sebagai remaja, namun sudah bisa dikatakan sebagai orang dewasa. Umumnya mahasiswa di perguruan tinggi sudah mencapai usia di atas 18 tahun. Pendekatan pembelajaran tentu tidak lagi menggunakan pendekatan pedagogi (pendidikan untuk anak-anak), tetapi menggunakan pendekatan andragogi (pendidikan untuk orang dewasa) (Yusuf \& Sohiron, 2019).

Berdasarkan penelitian terdahulu oleh Rahman \& Elshap (2016) yang meneliti implementasi kekuatan motivasi belajar dalam pendekatan andragogi, diperoleh hasil bahwa pendekatan andragogi memberikan dampak yang cukup besar dalam membangun motivasi belajar mahasiswa dalam intensitas perkuliahan, penugasan, evaluasi, dan capaian kriterita kelulusan kuliah yang membaik. Sejalan dengan itu, penelitian Djumena (2016) mengenai implementasi pembelajaran orang dewasa pada mahasiswa pendidikan luar sekolah, FKIP Untirta, menunjukkan hasil yang positif. Ketika dosen menerapkan pendekatan andragogi dalam pembelajaran, memotivasi mahasiswa untuk belajar mandiri,

Silampari Bisa: Jurnal Penelitian Pendidikan Bahasa Indonesia, Daerah, dan Asing Vol. 4, No. 2, 2021 
membangun kerja sama, mampu memecahkan masalah, serta membangun pembelajaran yang interaktif.

Pada studi pendahuluan, wawancara dengan salah seorang dosen FKIP, rata-rata mahasiswa di semester pertama dan kedua memang mengalami masa transisi dalam peyesuaian pola belajar di perguruan tinggi. Namun, ada juga ditemukan mahasiswa yang sudah berada di semester 5 dan 6 masih belum mandiri dalam menumbuhkan motivasi dan minat belajarnya sendiri. Hal ini tentu menjadi tantangan tersendiri bagi dosen untuk melakukan bimbingan akademis kepada mahasiswa tersebut.

Metode perkuliahan yang dilakukan oleh dosen sangat berpengaruh terhadap hasil yang nantinya akan dicapai oleh mahasiswa, baik itu mencakup pada proses belajar-mengajar, penugasan, maupun pada saat ujian. Menurut Undang-undang Republik Indonesia Nomor 12 Tahun 2012 tentang Pendidikan Tinggi, pendidikan adalah usaha sadar dan terencana untuk mewujudkan suasana belajar dan proses pembelajaran agar peserta didik secara aktif mengembangkan potensi dirinya untuk memiliki kekuatan spiritual keagamaan, pengendalian diri, kepribadian, kecerdasan, akhlak mulia, serta keterampilan yang diperlukan dirinya, masyarakat, bangsa, dan negara. Oleh karena itu, mahasiswa yang belajar di perguruan tinggi sudah memiliki tujuan belajar yang jelas dan kesadaran penuh terhadap apa yang dilakukannya.

Selanjutnya menurut UU tersebut, Pendidikan Tinggi adalah jenjang pendidikan setelah pendidikan menengah yang mencakup program diploma, program sarjana, program magister, program doktor, dan program profesi, serta program spesialis, yang diselenggarakan oleh perguruan tinggi berdasarkan kebudayaan bangsa Indonesia. Pendidik di perguruan tinggi atau dosen memegang peranan penting dalam membimbing mahasiswa untuk mencapai hasil belajar yang optimal. Dosen dianggap sebagai pendidik profesional karena memiliki kualifikasi akademis dengan rata-rata pendidikan minimal Strata 2 dan memiliki keahlian di bidangnya. Seorang dosen sudah tentu harus memahami hakikat belajar-mengajar di perguruan tinggi, termasuk menggunakan metode dan pendekatan pembelajaran yang sesuai dengan karakteristik mahasiswa.

Dalam setiap tingkat pendidikan, memiliki tantangan dan karakteristik yang berbeda. Pendekatan dalam mengajar anak usia sekolah dasar, berbeda dengan anak usia sekolah menengah, begitu pula usia dewasa/mahasiswa. Rahman \& Elshap (2016) menjelaskan bahwa belajar bagi orang dewasa berkaitan dengan bagaimana mengarahkan diri sendiri untuk bertanya dan mencari jawabannya sendiri. Orang dewasa yang mempunyai banyak pengalaman dan pengetahuan, orang dewasa yang cenderung susah berkonsentrasi, sensitif, tidak percaya diri dan selalu ingin dihargai merupakan tantangan bagi para pendidik.

Ada beberapa definisi tentang pembelajaran andragogi, diantaranya menurut Rosyanafi (2012), pembelajaran orang dewasa atau sering dikenal dengan istilah andragogi merupakan sebuah metode pembelajaran yang digunakan dalam proses pembelajaran dengan sasaran orang dewasa. Hiryanto

Silampari Bisa: Jurnal Penelitian Pendidikan Bahasa Indonesia, Daerah, dan Asing Vol. 4, No. 2, 2021 
(2017) berpendapat tentang konsepsi andragogi, yaitu sebagai istilah pendidikan orang dewasa atau dapat diartikan sebagai pendidikan yang ditujukan untuk peserta didik yang telah dewasa atau berumur 18 tahun ke atas atau telah menikah dan memiliki kematangan, dan untuk memenuhi tuntutan tugas tertentu dalam kehidupannya.

Secara alamiah, orang dewasa memiliki kemampuan menetapkan tujuan belajar, mengalokasi sumber belajar, merancang strategi belajar dan, mengevaluasi kemajuan terhadap pencapain tujuan belajar secara mandiri. Helvita, Suratman, \& Sofino (2017), merumuskan 3 kategori pendidikan orang dewasa (andragogi), sebagai berikut.

1) Pendidikan orang dewasa adalah ilmu membantu atau memfasilitasi orang dewasa belajar

2) Kegiatan pendidikan orang dewasa terorganisir.

3) Pendidikan orang dewasa bertujuan untuk meningkatkan kemampuan serta partisipasi peserta didik.

Penerapan pendekatan andragogi di perguruan tinggi, terutama pada Program Studi Pendidikan Bahasa Indonesia, diharapkan membawa dampak positif bagi mahasiswa maupun dosen. Dampak tersebut dapat berupa meningkatnya kemampuan belajar, kemampuan memotivasi belajar sendiri, dan menumbuhkan kesadaran terhadap tujuan belajar mahasiswa. Sejalan dengan hal itu, Rosania, Yuni, \& Mujib (2019) menyatakan bahwa pendekatan andragogi dapat berpengaruh terhadap kemampuan menyelesaikan soal matematika.

Pendekatan andragogi spiritual memberikan kebebasan kepada mahasiswa untuk menumbuhkan kemandirian belajar, kesadaran terhadap pengembangan potensi diri, dan motivasi untuk meraih tujuan belajar. Beberapa penelitian pendekatan andragogi pada proses pembelajaran sudah pernah dilakukan, namun penelitian pendekatan andragogi spiritual belum pernah ada yang menerapkannya di perguruan tinggi. Oleh karena itu, rumusan masalah dalam penelitian ini adalah bagaimana implementasi/penerapan pendekatan andragogi spiritual pada perkuliahan di Program studi pendidikan Bahasa Indonesia FKIP-UMB.

Basleman Anisah, dalam Setyawan (2017) mengemukakan prinsip pembelajaran andragogi sebagai berikut.

1) Readiness (Kesiapan untuk Belajar)

Peserta didik dapat mencapai hasil belajar yang baik, apabila sebelumnya pengajar menyiapkan kondisi peserta didik baik secara fisik maupun mental. Penyampaian Kondisi fisik dapat terwujud dengan penyediaan ruangan dan sarana yang sesuai dengan tujuan pelatihan. Sedangkan penyiapan secara mental dapat terciptakan dengan berbagai cara yang dimaksudkan agar peserta merasa tertarik untuk belajar, merasa senang, tidak malu, tidak takut, dan timbul semangat untuk belajar. Untuk itu, maka perlu diberikan ice breaking sebelum masuk materi yang sebenarnya.

2) Sequencing (Tahapan Belajar)

Seseorang akan lebih mudah belajar jika materi pelajaran diberikan setahap demi setahap satu bagian dari yang mudah menuju ke yang sulit. Implikasinya

Silampari Bisa: Jurnal Penelitian Pendidikan Bahasa Indonesia, Daerah, dan Asing Vol. 4, No. 2, 2021 
dengan penyelenggaraan diklat adalah dalam penyusunan jadwal mata diklat harus setahap demi setahap dan saling melengkapi satu dengan yang lain. Tahapan pembelajaran tidak boleh bolak-balik sesuai dengan keinginan fasilitator.

3) Understanding (Pemahaman)

Seseorang peserta belajar dapat belajar dengan baik, jika ia mengerti apa yang akan dipelajari, untuk apa ia belajar dan kemampuan apa yang akan dimiliki setelah ia selesai mempelajari pelajaran tertentu. Berkaitan dengan hal ini maka dalam awal pembelajaran perlu dijelaskan tujuan pembelajaran umum dan tujuan pembelajaran khususnya.

4) Participation (Peran Serta)

Belajar dapat terjadi melalui peran serta secara aktif dari orang yang belajar, baik secara fisik maupun mental. Oleh karena itu, tata ruang diklat perlu disusun agar dapat memberikan keleluasaan peserta diklat berperan aktif dalam proses pembelajaran. Seperti tempat duduk yang mudah dipindahkan, layout ruangan dalam bentuk letter $U$ dan lain sebagainya.

5) Feed Back (Umpan Balik)

Belajar akan lebih semangat jika peserta mengetahui hasil belajar yang telah mereka capai mungkin sudah benar, belum benar atau salah. Ini semua harus mereka ketahui agar dapat memperbaiki. Feedback bagi orang dewasa perlu diperhatikan dengan niat yang tulus dan tidak mempermalukan di depan umum. Contoh dengan melalui latihan-latihan, kemudian peserta diminta untuk mengomentari sendiri hasil yang telah diperoleh serta dimintai saran bolehkah diberikan masukan dari pihak lain.

6) Reinforcement (Pemantapan/Penguatan)

Pemantapan merupakan hal yang penting dalam proses belajar. Pemantapan ini dapat dilakukan dengan remedial maupun dengan pujian. Kesuksesan dalam belajar juga merupakan pemanfaatan sekaligus pendorong untuk lebih berhasil dalam proses belajar berikutnya.

7) Motivasi Belajar

Motivasi belajar akan timbul apabila terkait dengan kebutuhannya. Jika memperhatikan mengenai kebutuhan maka dapat mengacu pada kebutuhan yang dimiliki manusia yang dikemukakan oleh Maslow (1994). Fasilitator perlu mengaitkannya dengan proses pembelajaran.

8) Persepsi

Belajar akan lebih efektif apabila terjadi usaha menghubungkan antara materi pelajaran dengan pengertian atau pemahaman yang sudah dimiliki oleh peserta. Sebagai contoh untuk menjelaskan pentingnya tujuan pembelajaran dalam proses pembelajaran maka widyaswara perlu menggali peserta diklat tentang pentingnya tujuan dalam artian umum, kemudian pentingnya tujuan hidup dalam suatu kehidupan, baru fasilitator memproses dengan materi yang akan disajikan yaitu tentang perlunya tujuan pembelajaran bagi seorang instruktur.

Silampari Bisa: Jurnal Penelitian Pendidikan Bahasa Indonesia, Daerah, dan Asing Vol. 4, No. 2, 2021 
Jamiatul Hamidah, Akhmad Syakir

Implementasi Pendekatan Andragogi Spiritual dalam Meningkatkan Motivasi Belajar Mandiri Mahasiswa pada Program Studi Pendidikan Bahasa Indonesia FKIP Universitas Muhammadiyah Banjarmasin

\section{9) Application (Penerapan)}

Belajar akan lebih mudah jika peserta melihat relevansinya dan dapat diterapkan pada situasi kerja. Aplikasi merupakan salah satu hal yang harus terjadi dalam proses belajar setelah sebelumnya didahului dengan pengertian dan pemahaman atas pengetahuan dasarnya. Oleh karena itu, dalam proses pembelajaran perlu diciptakan metode pembelajaran yang lebih menitikberatkan pada penerapan-penerapan seperti metode praktik, simulasi, main peran, dan lain sebagainya.

10) Transfer of Learning (Alih Belajar)

Melalui tahap aplikasi, dimungkinkan dapat sampai pada tahap generalisasi yaitu pemanfaatan atau penggunaan hasil belajar untuk memudahkan belajar dalam keadaan lain.

Pendapat lain mengenai prinsip andragogi yaitu menurut Bagaskara (2019) mengemukakan penerapan prinsip andragogi dalam proses pembelajaran, yaitu: pertama, menciptakan suasana belajar yang menyenangkan, agar dapat mengembangkan self concept warga belajar, perlu diciptakan suatu suasana hidup dalam dunia mereka. Kedua, situasi belajar antara lain lingkungan fisik yang menyenangkan, perlengkapan dan peralatan yang berukuran sesuai dengan warga belajar, ruang pertemuan diatur secara informal, dan dekorasi sesuai kesenangan mereka. Ketiga, identifikasi kebutuhan para warga belajar dilakukan bersama antara warga belajar dan tutor sehingga dapat diketahui keadaan sesungguhnya. Keempat, pengalaman belajar disusun bersama antara warga belajar dan tutor sehingga akan merasakan adanya kepemilikan terhadap materi yang akan disampaikan. Mengajar tutor diartikan sebagai "the efforts of making person learn" (usaha membuat warga belajar). Evaluasi dilakukan dengan penilaian diri sendiri. Penentuan keberhasilan belajarnya ditentukan oleh warga belajar. Tugas tutor sebagai fasilitator dalam evaluasi diri sendiri.

Seperti telah disebutkan sebelumnya, andragogi adalah pendekatan pembelajaran untuk orang dewasa. Maka andragogi spiritual dapat dikatakan sebagai sebuah pendekatan pembelajaran bagi orang dewasa yang menekankan pada spirit atau kejiwaan peserta didik (dewasa). Menurut Chulsum \& Novia (2006), spiritual berkenaan dengan kejiwaan, atau berhubungan dengan rohani. Kesempurnaan spiritual merupakan salah satu kebutuhan dasar bagi manusia dalam mengarungi kehidupan (Arifin, 2015:107).

Pada tahap usia dewasa, pendekatan pedagogi tidak lagi tepat untuk diterapkan dalam pendidikan, dan pendekatan andragogi dianggap lebih tepat. Rosidin (2013) mengemukakan perbedaan pedagogi dan andragogi berkaitan dengan pribadi peserta didik, seperti konsep tentang siswa, pengalaman siswa, kesiapan belajar, orientasi terhadap belajar dari motivasi belajarnya. Asumsi tersebut dapat dibedakan dari segi prosesnya yang antara lain berupa unsur suasana, perencanaan, diagnosis kebutuhan, rumusan tujuan, rencana pelajaran, kegiatan belajar, dan penilaian.

Burkhardt dalam Ivones (2015), menyebutkan aspek-aspek spiritual meliputi (1) hal-hal yang berhubungan dengan sesuatu yang tidak diketahui atau

Silampari Bisa: Jurnal Penelitian Pendidikan Bahasa Indonesia, Daerah, dan Asing Vol. 4, No. 2, 2021 
ketidakpastian dalam kehidupan, (2) menemukan arti dan tujuan hidup, (3) menyadari kemampuan untuk menggunakan sumber dan kekuatan dalam diri sendiri, dan (4) mempunyai perasaan keterikatan dengan diri sendiri dan dengan yang maha tinggi. Dengan demikian, dapat disimpulkan bahwa andragogi spiritual berkaitan dengan pendekatan pembelajaran bagi orang dewasa dengan melibatkan kesadaran jiwa terhadap kekuatan dalam diri dan kekuatan dari Tuhan. Salah satu pelibatan tersebut adalah dengan menyisipkan konsep keagamaan dalam pembelajaran.

Selanjutnya Rosidin (2013) menyatakan bahwa dalam Islam, orang dewasa menempati posisi urgen. Hal ini disebabkan objek mayoritas ajaran Islam adalah orang mukalaf. Definisi mukalaf mencakup kedewasaan dari segi biologis dan dari segi psikis-intelektual. Implikasinya, Islam memberikan ruang yang luas bagi terjadinya interaksi pendidikan orang dewasa (mukalaf) agar mereka dapat melaksanakan ajaran Islam dengan sebaik-baiknya. Pada perguruan tinggi Muhammadiyah, konsep Al Islam Kemuhammadiyahan menjadi salah satu pembelajaran wajib yang diajarkan, baik dalam mata kuliah tersendiri maupun disisipkan dalam setiap mata kuliah lainnya sebagai penciri. Pada mata kuliah wajib Prodi Pendidikan Bahasa Indonesia, penanaman nilai Al Islam kemuhammadiyahan dilaksanakan oleh semua dosen, baik di dalam kelas maupun di luar kelas.

Beberapa penelitian terdahulu yang menggunakan pendekatan andragogi yaitu:

1) Penerapan Prinsip Andragogi dalam Pembelajaran untuk Membentuk Sikap Kewirausahaan Di Lembaga Kursus dan Pelatihan Buana Bordir Course, oleh Rosyanafi (2012).

2) Implementasi Kekuatan Motivasi Belajar dalam Pendekatan Andragogi, oleh Rahman \& Elshap (2016).

3) Implementasi Model Pembelajaran Orang Dewasa pada Mahasiswa Pendidikan Luar Sekolah FKIP-Untirta, oleh Djumena (2016).

4) Pedagogi, Andragogi, dan Heutagogi serta Implikasinya dalam Pemberdayaan Masyarakat, oleh Hiryanto (2017).

5) Proses Belajar Mengajar Kursus Komputer di LP2M El Rahma Kota Bengkulu Menggunakan Pendekatan Andragogi, oleh Helvita, Suratman, \& Sofino (2017).

6) Pendekatan Andragogi dalam Pembelajaran Bahasa Arab, oleh Setiawan (2017).

7) Reorientasi Teori Andragogi pada Proses Pembelajaran, oleh Bagaskara (2019).

8) Pendekatan Teori Belajar Andragogi terhadap Kemampuan Menyelesaikan Soal Matematika Ditinjau dari Gender, oleh Rosania, Mujib, \& Sari (2019).

Perbedaan penelitian ini dengan penelitian sebelumnya adalah pendekatan andragogi spiritual yang mana lebih menekankan pada keterlibatan emosi dan

Silampari Bisa: Jurnal Penelitian Pendidikan Bahasa Indonesia, Daerah, dan Asing Vol. 4, No. 2, 2021 
perasaan dalam memandang suatu hal dalam kehidupan. Untuk itu, rumusan masalah dalam penelitian ini adalah "Bagaimana implementasi pendekatan andragogi spiritual dalam meningkatkan motivasi belajar mandiri mahasiswa Prodi Pendidikan Bahasa Indonesia, FKIP Universitas Muhammadiyah Banjarmasin?" Tujuan penelitian ini adalah untuk mendeskripsikan penerapan pendekatan andragogi spiritual dalam perkuliahan untuk mengoptimalkan hasil belajar mahasiswa. Manfaat yang diharapkan dari penelitian ini adalah meningkatkan motivasi belajar mandiri mahasiswa, meningkatkan pemahaman dosen terhadap pendekatan andragogi spiritual, serta meningkatkan hasil belajar mahasiswa.

\section{B. Metode Penelitian}

Penelitian ini menggunakan metode deskriptif dengan pendekatan kualitatif. Metode ini dipilih karena sejalan dengan yang dikemukakan oleh Sukmadinata (2017:72) bahwa penelitian pendidikan deskriptif kualitatif bertujuan untuk mendeskripsikan implementasi sebuah pendekatan andragogi dengan menyajikan data secara apa adanya. Teknik pengumpulan data penelitian diperoleh dengan cara observasi, wawancara, dan pembagian angket. Observasi awal dilakukan dengan membagikan angket kepada mahasiswa baru untuk memperoleh informasi motivasi belajar mereka. Wawancara dilakukan kepada dosen pengampu mata kuliah terkait perencanaan, pelaksanaan, dan evaluasi pembelajaran selama satu semester. Kemudian, pada akhir semester, mahasiswa diberikan angket untuk menelusuri motivasi dan hasil belajar mereka.

Sumber data adalah dosen Prodi Pendidikan Bahasa Indonesia dan mahasiswa FKIP Universitas Muhammadiyah Banjarmasin. Jumlah sampel sebanyak 6 orang dosen dan 40 orang mahasiswa. Analisis data dilakukan dengan melalui beberapa tahapan, yaitu pengumpulan data, identifikasi data, menguraikan data, dan penarikan kesimpulan. Untuk menguji subjektivitas, validitas, dan realibilitas penelitian, dilakukan dengan mereview data oleh partisipan.

Penelitian ini dilakukan di Program Studi Pendidikan Bahasa Indonesia, FKIP, Universitas Muhammadiyah Banjarmasin. Dosen yang diamati berjumlah 6 orang yaitu 4 orang dosen Prodi Pendidikan Bahasa Indonesia dan 2 orang dosen pengampu Mata Kuliah AI Islam Kemuhammadiyahan (AIK). Mahasiswa yang diuji sebagai sampel berjumlah 40 orang. Waktu penelitian ini adalah 1 tahun terhitung dari studi pendahuluan sampai laporan pertanggungjawaban.

\section{Hasil Penelitian dan Pembahasan \\ 1. Hasil Penelitian}

Berdasarkan hasil studi pendahuluan melalui kuesioner yang disebarkan kepada 40 orang mahasiswa, diperoleh data bahwa 95\% mahasiswa sudah memiliki kesadaran dalam dirinya sendiri terhadap tujuannya kuliah. Namun demikian, hanya $45 \%$ yang menyatakan mempunyai minat belajar mandiri tanpa harus menunggu arahan dari dosen. Peralihan masa SMA ke masa kuliah, tentunya mengubah cara belajar mahasiswa yang tadinya terbiasa menerima apa 
yang diberikan oleh guru, beralih menjadi keharusan untuk belajar mandiri. Sebanyak 52,5\% mahasiswa yang menjawab "mungkin", dalam artian dia belum menyadari sepenuhnya apakah dia sudah memiliki motivasi sendiri untuk belajar mandiri.

Selanjutnya, seluruh mahasiswa menyatakan memiliki cara sendiri untuk memotivasi dirinya agar selalu semangat dalam belajar maupun mengerjakan tugas. Dalam hal ini, jawaban mahasiswa beragam, seperti: motivasi datang dari orang tua/keluarga, motivasi dari sendiri, dan beberapa dari orang yang menjadi panutan/idola mereka. Pada poin pertanyaan "apakah Anda termasuk orang yang mudah menyerah dan mengeluh ketika banyaknya tugas yang diberikan oleh dosen?" $5 \%$ menjawab ya, 32,5 \% menjawab tidak, dan 62,5\% menjawab mungkin.

Selanjutnya, mahasiswa mengemukakan kendala yang mereka hadapi selama masa awal perkuliahan, yaitu faktor internal dan faktor eksternal mahasiswa. Secara internal, mahasiswa menyatakan kendala yang mereka hadapi adalah kesulitan untuk beradaptasi baik dengan teman sekelas, dosen, maupun metode pembelajaran daring yang sejak awal pandemi tahun 2020 mulai diterapkan. Sebagian besar mahasiswa mengaku kesulitan dalam memahami materi perkuliahan selama pembelajaran daring. Apalagi jika dosen banyak memberikan tugas dan kurangnya penjelasan materi yang diberikan membuat mahasiswa merasa kesulitan dalam memahami materi perkuliahan. Faktor eksternal yang menjadi kendala mahasiswa pada masa awal perkuliahan adalah jaringan internet yang tidak stabil di daerah mereka tinggal yang akhirnya mengganggu proses perkuliahan secara daring. Selain itu, dosen memberikan tugas terlalu banyak dengan batas waktu yang dirasa singkat. Umpan balik yang diberikan oleh dosen terhadap tugas yang diberikan juga dirasa kurang, sehingga motivasi belajar mahasiswa menurun.

Berdasarkan penelitian yang dilakukan terhadap 40 orang mahasiswa dan 6 orang dosen di Program Studi S-1 Pendidikan Bahasa Indonesia, setelah penerapan pendekatan andragogi spiritual dalam pembelajaran, maka diperoleh hasil bahwa penerapan pendekatan andragogi spiritual dapat meningkatkan motivasi dan hasil belajar mahasiswa. Hasil tersebut diketahui berdasarkan analisis terhadap wawancara kepada dosen dan penelusuran melalui angket yang dibagikan kepada mahasiswa. Penerapan andragogi spiritual dilakukan oleh dosen mulai dari persiapan pembelajaran, pada proses kegiatan pembelajaran, sampai kegiatan penilaian atau evaluasi.

\section{Pembahasan}

Berdasarkan hasil penelitian yang dilakukan, diketahui bahwa pendekatan andragogi spiritual yang dilakukan oleh dosen pengampu Mata Kuliah pada Program Studi Pendidikan Bahasa Indonesia, FKIP Universitas Muhammadiyah Banjarmasin, diterapkan dalam tiga tahapan, yaitu tahap persiapan pembelajaran, tahap pelaksanaan proses pembelajaran, dan tahap evaluasi atau penilaian. Dari

Silampari Bisa: Jurnal Penelitian Pendidikan Bahasa Indonesia, Daerah, dan Asing Vol. 4, No. 2, 2021 
ketiga aspek tersebut, dosen melaksanakan dengan berlandaskan spirit Al Islam Kemuhammadiyahan

a) Persiapan Pembelajaran

Sebelum mulai tahun akademik atau sebelum perkuliahan berjalan, dosen pengampu mata kuliah menyiapkan Rencana Pembelajaran Semester (RPS). RPS disusun oleh pengampu mata kuliah dan divalidasi oleh ketua program studi. Pengumpulan RPS ke bagian akademik fakultas, wajib dilakukan oleh dosen paling lambat 7 hari sebelum perkuliahan dimulai. Untuk mata kuliah Al Islam Kemuhammadiyahan (AIK) yang merupakan mata kuliah wajib di perguruan tinggi Muhammadiyah, seperti AlK 1 (Pendidikan Agama), AIK 2 (Ibadah, Akhlak, dan Muamalah), AIK 3 (Kemuhammadiyahan), dan AIK 4 (Islam dan IPTEKS), mata kuliah tersebut sudah tersedia RPS nya yang disusun oleh Majelis Dikti Litbang PTM.

Dalam penyusunan RPS, dosen pengampu mata kuliah melibatkan pihak lain, seperti teman sejawat atau mahasiswa. Pelibatan teman sejawat dipilih berdasarkan pengampu mata kuliah yang serumpun atau yang berkelanjutan, sehingga dapat mengitegrasikan pengetahuan $A$ dan $B$ secara maksimal, atau sebaliknya untuk menghindari terjadinya tumpang tindih materi $A$ dan $B$. Sedangkan pelibatan dari mahasiswa bertujuan untuk menganalisis kebutuhan yang diharapkan oleh mahasiswa dapat dipenuhi pada mata kuliah tersebut.

Dalam RPS yang disusun oleh dosen pengampu mata kuliah maupun dalam tahap persiapan kegiatan proses pembelajaran, dosen mengintegrasikan nilai-nilai keagamaan. Sebagai kampus yang menjunjung tinggi nilai Islam, di Universitas Muhammadiyah Banjarmasin menyiapkan sarana prasarana yang islami. Sebagai contoh di ruang kelas diletakkan tulisan-tulisan doa, di selasar kampus, diletakkan kalimat motivasi islami, hadis-hadis, dan kata-kata mutiara dari tokoh terkenal seperti K.H. Ahmad Dahlan (pendiri organisasi Muhammadiyah). Di samping itu, dosen pengampau mata kuliah membiasakan mahasiswa untuk selalu berdoa ketika akan memulai perkuliahan.

Dari segi materi yang disiapkan, dosen pengampu juga mengintegrasikan nilai-nilai Islam. Sebagai contoh materinya biasanya dikaitkan dengan apa yang terkandung dalam AI Quran. Pada Mata Kuliah Islam dan IPTEKS, biasanya dosen memulai dengan ayat seperti IQRA, yang artinya bacalah. Kemudian, dosen akan bahas terlebih dahulu mengenai kata lqra, menurut pendapat ahli seperti Qurais Shihab, atau Al Qurtubi, kemudian mengapa demikian. Lalu mahasiswa diarahkan kepada ilmu pengetahuan. Sebagai contoh dosen mengajar mengenai karya monumental. Dosen membahas tentang kabah, ilmu pengetahuan yang dibawa Nabi Adam seperti mengolah baju dari kulit kayu, membuat api dari batu, dan lainnya. Kemudian, dalam kegiatan pembelajaran, dosen juga merancang refleksi kesyukuran kepada Sang Pencipta.

Setelah RPS siap, maka tahap selanjutnya dosen menyiapkan hal-hal yang akan dilakukan atau disampaikan pada kegiatan proses pembelajaran, baik secara tatap muka maupun daring. Hal-hal yang disiapkan antara lain power point, video, 
Jamiatul Hamidah, Akhmad Syakir

Implementasi Pendekatan Andragogi Spiritual dalam Meningkatkan Motivasi Belajar Mandiri Mahasiswa pada Program Studi Pendidikan Bahasa Indonesia FKIP Universitas Muhammadiyah Banjarmasin

metode pelaksanaan kegiatan, buku penunjang, rumusan tujuan pembelajaran, materi, dan evaluasi (baik tugas maupun ujian untuk penilaian).

\section{b) Pelaksanaan Kegiatan Proses Pembelajaran/Perkuliahan}

Dalam kegiatan perkuliahan, baik secara tatap muka maupun secara daring melalui media virtual, dosen tetap melakukan pendekatan pendidikan andragogi. Sebagai contoh, apabila ada materi perkuliahan yang tidak dipahami oleh mahasiswa, dosen selalu memberikan kesempatan untuk bertanya atau berdiskusi. Karena bentuk apresiasi atau kedewasaan dosen mengajar itu sendiri adalah memberi ruang dan waktu kepada mahasiswa untuk berpikir. Bahkan ada dosen yang memulai menyampaikan materi tidak dengan metode ceramah. Akan tetapi dimulai dengan bertanya, karena bertanya itu adalah asal muasal dari lahirnya sebuah ide. Melalui pertanyaan yang diajukan kepada mahasiswa, mengajak mereka untuk berpikir kritis, mengurai suatu masalah, dan berusaha untuk memecahkan masalah tersebut.

Untuk menciptakan suasana kuliah yang kondusif dan efisien, dosen melakukan kontrak perkuliahan dengan mahasiswa terkait tata tertib yang harus ditaati bersama. Begitu pula dalam kegiatan pembelajaran daring, kontrak perkuliahan tetap dilaksanakan. Contoh aturan adalah jika dosen sedang berbicara di ruang zoom meeting, maka mahasiswa wajib mematikan audio agar tidak mengganggu. Nanti setelah diberi kesempatan bicara atau bertanya pada sesi diskusi, baru mahasiswa boleh menyalakan audio secara bergantian. Di samping itu, dosen selalu memberikan kesempatan kepada mahasiswa untuk bertanya terkait materi yang belum mereka pahami. Untuk menciptakan perkuliahan yang efisien, dosen juga selalu mengupayakan agar hadir dalam perkuliahan sesuai jadwal dan tepat waktu. Memenuhi kewajiban jumlah pertemuan minimal 14 kali, serta mengisi perkuliahan sesuai alokasi waktu yang tersedia dengan mengkombinasi berbagai metode pembelajaran, tidak hanya ceramah, namun memberikan kesempatan seluas-luasnya kepada mahasiswa untuk mengeksplorasi dirinya.

Untuk menumbuhkan kemandirian belajar mahasiswa, hal-hal yang dilakukan dosen adalah: 1) memberikan mahasiswa inisiasi untuk membaca sendiri bukubuku yang relevan dengan pembelajaran; 2) memotivasi, memberikan contohcontoh yang baik, dan membuka wawasan mereka seluas-luasnya; 3) dengan memberi tugas analisis sesuai materi atau menerapkannya langsung; 4) memberi kesempatan untuk memantau kemajuan belajarnya sendiri dan mengevaluasi hasil belajaranya. Selain itu juga mendorong mahasiswa untuk mengikuti kegiatan organisasi, karena mahasiswa bisa mendapatkan pengalaman, motivasi, dan bisa berbagi melalui organisasi.

Melalui kegiatan organisasi, mahasiswa memiliki kesempatan untuk membangun kesadaran diri terhadap potensi serta upaya untuk mengembangkan potensi diri. Meskipun demikian, di dalam kelas dosen tetap berupaya untuk mengembangkan potensi mahasiswa. Upaya tersebut antara lain: 1) memberikan

Silampari Bisa: Jurnal Penelitian Pendidikan Bahasa Indonesia, Daerah, dan Asing Vol. 4, No. 2, 2021 
tujuan dan hakikat hidup sebagai seorang manusia yang bisa memanusiakan manusia; 2) memberikan motivasi, mengarahkan minat dan bakatnya sesuai dengan kepribadiannya; 3) mengatakan kepada mereka bahwa semua orang bisa, yang tidak bisa adalah orang yang malas; dan 4) menerapkan kebiasaan baik untuk mencoba hal-hal baru. Selain itu, kegiatan yang dilakukan di dalam kelas untuk mengembangkan potensi mahasiswa adalah dengan melatih mahasiswa dengan menjadi moderator, terutama mahasiswa yang pendiam. Mengaktifkan seluruh mahasiswa di dalam kelas dengan memberi kesempatan untuk berbicara menyatakan pendapat atau bertanya.

Pada hakikatnya pembelajaran pada orang dewasa, dosen berperan sebagai fasilitator dan motivator. Mahasiswa selayaknya mampu menumbuhkan sendiri motivasinya untuk belajar mandiri. Namun, berdasarkan studi pendahuluan, motivasi belajar mahasiswa dominan berasal dari diri sendiri dan keluarga. Maka pada Program Studi Pendidikan Bahasa Indonesia FKIP Universitas Muhammadiyah Banjarmasin, dosen juga memberikan motivasi kepada mahasiswa untuk belajar mandiri. Cara-cara yang dilakukan oleh dosen yaitu 1) memastikan tujuan belajar sesuai dengan cara yang digunakan; 2) memberikan gambaran masa depan yang diinginkan agar mahasiswa termotivasi; 3) sering melakukan refleksi tentang gambaran perjuangan orang-orang yang berhasil; 4) selalu mengingatkan terus tujuan mereka belajar; serta 5) menceritakan pengalaman pribadi dosen.

\section{c) Penilaian/Evaluasi}

Dalam hal penilaian, dosen senantiasa terbuka kepada mahasiswa. Selama pembelajaran daring, umumnya dosen menggunakan media Google Class Room, yang di dalamnya menyediakan kolom tugas. Ketika mahasiswa mengumpulkan tugasnya, dosen selalu mengisi penilaian dan mengembalikannya kepada mahasiswa. Jadi secara berkala mahasiswa dapat mengecek hasil pekerjaan yang dilakukan. Untuk penilaian yang berupa ujian, baik tengah semester maupun akhir semester, dosen memberikan secara terbuka nilai yang diperoleh secara terbuka. Namun, cara dosen menyampaikan nilai kepada mahasiswa berbeda-beda. Ada yang langsung membagikan daftar nilai yang diperoleh mahasiswa, ada juga yang menunggu mahasiswa bertanya atau meminta daftar nilai. Dosen pengampu mata kuliah juga menekankan bahwa setiap perbuatan selalu ada nilainya. Jadi, mahasiswa juga dapat mengukur sendiri nilainya berdasarkan kemampuan dan usaha yang dia lakukan.

d) Pemahaman Dosen terhadap Pendekatan Pendidikan Andragogi Spiritual

Berdasarkan hasil pengamatan dan wawancara kepada seluruh dosen pengampu mata kuliah yang ada di Program Studi Pendidikan Bahasa Indonesia, umumnya mereka telah memahami pendekatan pendidikan andragogi. Hal ini ditunjukkan dari bagaimana dosen menyiapkan perkuliahan, hingga dalam proses kegiatan perkuliahan. Sebagai kampus yang memiliki ciri islami, dengan visi mencetak generasi Islam berkemajuan dan berkarakter islami, maka dosen 
pengampu mata kuliah mengintegrasikan nilai Al Islam Kemuhammadiyahan dalam seluruh aspek, termasuk perkuliahan. Hal ini yang menjadi kelebihan dosen di Perguruan Tinggi Muhammadiyah, khususnya Universitas Muhammadiyah Banjarmasin, pada Prodi Pendidikan Bahasa Indonesia.

Meskipun demikian, ada beberapa kendala yang dihadapi oleh dosen dalam menerapkan pedekatan pendidikan andragogi spiritual. Kendala tersebut adalah seperti ruang gerak yang dihadapi mahasiswa cukup luas sehingga hal ini kadang memengaruhi aktivitas belajarnya; mahasiswa yang malas dan cepat bosan; latar belakang mahasiswa yang berbeda-beda; serta kendala yang paling banyak dihadapi saat ini adalah saat penerapan perkuliahan secara daring. Saat pelaksanaan pembelajaran daring, masalah yang dihadapi cukup kompleks, seperti jaringan internet yang tidak stabil, pengawasan terhadap keaktifan mahasiswa, terhambatnya komunikasi karena tidak bertemu langsung, dan mahasiswa sulit mengekspresikan dan mengeksplorasi dirinya dibandingkan ketika perkuliahan tatap muka.

\section{Simpulan dan Saran}

Berdasarkan uraian pembahasan di atas, dapat disimpulkan bahwa penerapan pendekatan andragogi spiritual pada perkuliahan pada Program Studi Pendidikan Bahasa Indonesia, FKIP Universitas Muhammadiyah Banjarmasin, dapat meningkatkan motivasi dan hasil belajar mahasiswa. Penerapan tersebut dilakukan oleh dosen mulai dari persiapan pembelajaran, pada proses kegiatan pembelajaran, sampai kegiatan penilaian atau evaluasi. Keterbatasan penelitian ini adalah pada jangka waktu pengamatan terhadap dosen dan mahasiswa yang berjalan satu semester. Saran bagi peneliti selanjutnya, dapat melakukan penelitian penerapan pendekatan andragogi terhadap mahasiswa, sejak awal mereka masuk kuliah, sampai mereka lulus.

\section{Daftar Pustaka}

Arifin, B. S. (2015). Psikologi Agama. Bandung: CV Pustaka Setia.

Bagaskara, R. (2019). Reorientasi Andragogi pada Proses Pembelajaran. Jurnal Pendidikan Rokania, 4(3).

Chulsum, U., \& Novia, W. (2006). Kamus Besar Bahasa Indonesia. Surabaya: Kashiko.

Djumena, I. (2016). Implementasi Model Pembelajaran Orang Dewasa pada Mahasiswa Pendidikan Luar Sekolah FKIP Untirta. Jurnal Eksistensi Pendidikan Luar Sekolah (E-Plus), https://jurnal.untirta.ac.id/index.php/E-Plus/article/view/1178. 
Helvita, H, Suratman, A., \& Sofino. S. (2017). Proses Belajar Mengajar Kursus Komputer Di LP2M El Rahma Kota Bengkulu Menggunakan Pendekatan Andragogi. Journal of Community Development (JPM), 1(1).

Hiryanto, H. (2017). Pedagogi, Andragogi, dan Heutagogi serta Implikasinya dalam Pemberdayaan Masyarakat. Dinamika Pendidikan, 22(1), https://journal.uny.ac.id/index.php/dinamika-pendidikan/article/view/19771

Ivones, J. (2015). Pengertian Spiritual. Tersedia: https://www.kompasiana.com/nezfine/55004cf3813311275efa76fd/pengertia n-spiritual. Diakses tanggal 23 Oktober 2020.

Maslow, A. H. (1994). Motivasi dan Kepribadian (Teori Motivasi dengan Pendekatan Hierarki Kebutuhan Manusia). Jakarta: PT PBP.

Rahman, A. \& Elshap, D. S. (2016). Implementasi Kekuatan Motivasi Belajar dalam Pendekatan Andragogi. EMPOWERMENT : Jurnal Ilmiah Program Studi Pendidikan Luar Sekolah, 5(2), 1-3, http://ejournal.stkipsiliwangi.ac.id/index.php/empowerment/article/view/548

Rosania, Y., Mujib, M., \& Sari, F. I. (2019). Pendekatan Teori Belajar Andragogi terhadap Kemampuan Menyelesaikan Soal Matematika Ditinjau dari Gender. Jurnal AKSIOMA, 8(1).

Rosidin. (2013). Konsep Andragogi dalam Al Quran, Sentuhan Islami pada Teori dan Praktik Pendidikan Orang Dewasa. Malang: Litera Ulul Albab.

Rosyanafi, R. J. (2012). Penerapan Prinsip Andragogi dalam Pembelajaran untuk Membentuk Sikap Kewirausahaan di Lembaga Kursus dan Pelatihan Buana Bordir Course. Jurnal J+PLUS UNESA, 1(1), https://ejournal.unesa.ac.id/index.php/jurnal-pendidikan-luarsekolah/article/view/2001

Setyawan, C. E. (2017). Pendekatan Andragogi dalam Pembelajaran Bahasa Arab. Al Mahara Jurnal Pendidikan Bahasa Arab, 3(2).

Sukmadinata, N. S. (2017). Metode Penelitian Pendidikan. Bandung: PT Remaja Rosdakarya. 
Jamiatul Hamidah, Akhmad Syakir

Implementasi Pendekatan Andragogi Spiritual dalam Meningkatkan Motivasi Belajar Mandiri Mahasiswa pada Program Studi Pendidikan Bahasa Indonesia FKIP Universitas Muhammadiyah Banjarmasin

Undang-Undang Republik Indonesia Nomor 12 Tahun 2012 tentang Pendidikan Tinggi. (2012). Retrieved 4 Juli 2021, from BPK RI: https://peraturan.bpk.go.id/Home/Download/28456/UU\%20Nomor\%2012\%2 OTahun\%202012.pdf

Yusuf, M., \& Sohiron, S. (2019). Manajemen Pembelajaran Pendidikan Tinggi (Implementasi Kurikulum Berbasis KKNI pada Program Sarjana melalui Pendekatan Andragogi). Indonesian Journal of Islamic Educational Management, 2(2), 53. doi:10.24014/ijiem.v2i2.7897

Silampari Bisa: Jurnal Penelitian Pendidikan Bahasa Indonesia, Daerah, dan Asing Vol. 4, No. 2, 2021 